\title{
SHAPING PRODUCTIVE CULTURAL CONTENT FOR EFL MATERIALS IN CONTEMPORARY RUSSIAN ELT PRACTICES
}

\author{
Peter J. Mitchell ${ }^{1}$ \\ Andrei G. Shilnov ${ }^{2}$
}

\begin{abstract}
The article attempts to develop guidelines for the inclusion/non-inclusion of specific cultural content into EFL materials for contemporary ELT practices in Russia. Cultural circumstances surrounding the ELT practices in today's Russia and their connection with the past are analyzed. Some approaches to the usage of materials are considered, with examples of specific published and online materials provided. An exemplar of a lesson plan on a thought-provoking topic with sample activities and materials is presented based on the approaches and principles described. A conclusion is made on the necessity of offering teacher training on shaping productive cultural content for EFL materials that are appropriate to the teaching context.
\end{abstract}

Keywords: English language teaching (ELT). English as a foreign language (EFL). Textbook. Cultural content.

\section{A FORMAÇÃO DE CONTEÚDO CULTURAL PRODUTIVO PARA MATERIAIS} DE ILE EM PRÁTICAS DE ELI CONTEMPORÂNEAS RUSSAS

\section{RESUMO}

O artigo tenta desenvolver as diretrizes para a inclusão/não inclusão do conteúdo cultural específico nos materiais de ILE para práticas contemporâneas de ELI na Rússia. As circunstâncias culturais que envolvem as práticas de ELI na Rússia de hoje e sua conexão com o passado são analisadas. Algumas abordagens para o uso de materiais são consideradas, com exemplos de materiais específicos publicados e fornecidos on-line. Um exemplo de um plano de aula sobre um tópico instigante com atividades e materiais de amostra é apresentado com base nas abordagens e nos princípios descritos. A conclusão é feita sobre a necessidade de oferecer a formação de professores para moldar o conteúdo cultural produtivo para materiais ILE que são apropriados para o contexto de ensino.

PALAVRAS-CHAVE: Ensino de lingua inglêsa (ELI). Inglês como uma língua estrangeira (ILE). Livro didático. Contéudo cultural.

\footnotetext{
1 Tomsk State University. Orcid: https://orcid.org/0000-0001-9228-903X. peter_mitchell@mail.ru

2 National Research Tomsk State University. Orcid: https://orcid.org/0000-0001-5831-449X. shilnoff_andrey@mail.ru
} 


\section{THE RUSSIAN ELT CONTEXT}

The English language has been taught widely in Russia since the end of World War II when the world divided into two spheres of influence - capitalist and communist. Learning a foreign language - in practice, English - is compulsory in all schools. It is also mandated for all students in higher education. Yet the issue of selecting and implementing EFL content in Russia has historically been rather controversial. The cultural circumstances surrounding the ELT practices in today's Russia can be linked to the country's past. After the Revolution of 1917, the early years of the Soviet era saw a very negative attitude towards learning foreign languages in general (RASSOKHA, 2004, p. 41). Nevertheless, a decade later foreign languages were returned to both school and university curricula (TER-MINASOVA, 2009, p. 9). During the remaining decades of the Soviet era, the Iron Curtain and the official guidelines from the Soviet Ministry of Education kept EFL learners almost entirely isolated from the world where the English language was naturally used, and access to contemporary authentic materials was denied (IVANOVA; TIVYAEVA, 2015, p. 316). University students typically studied the language from the works of British writers such as J. Galsworthy and Ch. Dickens (RASSOKHA, 2004, p. 42). A report by a delegation of British education specialists who visited the Soviet Union in 1962 describes EFL materials in the USSR as "suspect", "unidiomatic" and "not particularly satisfactory from the standpoint of linguistic authenticity" (LEWIS, 1962, p. 11).

Under such circumstances, teaching and practicing productive skills (i.e. producing oral and written language for communication (DAVIES, 1976, p. 441)) in an authentic manner was irrelevant since learners had no opportunity for authentic communication (RASSOKHA, 2004, p. 42). Curricula for all courses and subjects were strictly censored, and there was no room for controversial topics that could stimulate learners' productive skills because many of these topics were taboo in Soviet society in general. The impact of the Soviet teacher-centered ELT practices can still be felt now, and one of the most recent studies carried out at a major Russian university revealed that classroom interactions are still "limited to individual and whole-class activities with the predominance of teacher talk" RASSKAZOVA; GUZIKOVA; GREEN, 2017, p. 6).

Perestroika and the subsequent collapse of the Soviet Union brought new changes and challenges for ELT in Russia. On the one hand, they led to new goals and created a new type of language learner. On the other hand, teachers found themselves unprepared for these changes, particularly in terms of ELT materials. Thus, many ELT courses were still of poor quality. Nevertheless, the door to Western publications, authentic materials and mass communication was open, and a new type of learner emerged "more open, less inhibited, and much more pragmatically oriented" (TER-MINASOVA, 2013). Other positive developments included student-focused approaches, the removal of ideological principles from course content, and the introduction of communicative teaching methods (IVANOVA; TIVYAEVA, 2015, p. 309).

It is unfortunate, though, that many schools and higher education institutions have not paid due attention to innovations in teaching methods and internationally-recognized best practice. In spite of attempts going as far back as the late Soviet period to update teaching methods in line with modern international practice (MONK, 
1986), the default system of teaching English in Russia in many institutions is very much old-fashioned: teacher-centered, with an over-reliance on textbooks and a lack of communication practice and using authentic English in situations which simulate real life (TER-MINASOVA, 2005, 2006). Wilga Rivers (2007) emphasizes the importance of avoiding the "artificial types of drills and practice exercises to which many learners are still subjected" in favor of having "practice in using the language for the normal purposes language serves in everyday life", citing Jespersen's observation that language textbooks often give the impression that learners "must be strictly systematical beings, who one day speak merely in futures, another day in [past tenses] and who say the most disconnected things only for the sake of being able to use all the persons in the tense which for the time being happens to be the subject..." (JESPERSON, 1904, p. 17-18).

Despite great changes since Jespersen's time, modern day language textbooks are not closely aligned to the real world (CHAN, 2013). Such a disjointed approach to language learning and teaching cannot but cause problems in terms of developing proficiency in a foreign language. It is not enough to include English as a subject in Russian school and university curriculums; there is now an acceptance that improvements in teaching English as a foreign language need to be made in order that learners achieve intercultural communicative competence and are motivated to learn (TER-MINASOVA, 2005; OBDALOVA, 2008).

The reluctance of some teachers to embrace new approaches to their professional practice is all the stranger since in contemporary Russia "there are no limitations as regards the course content and topics discussed in class, the only exception being the propaganda of terrorism, extremism, ethnic violence and intolerance" (IVANOVA; TIVYAEVA, 2015, p. 317), which is - for obvious reasons - prohibited by federal law. Indeed, teachers are endowed with much autonomy to select the means (materials and methods) of achieving state-mandated goals (the results of learning as determined in the state educational standards). In some cases, however, this can prove to be a double-edged sword.

Teachers are, therefore, free to choose authentic supplementary materials on a variety of topics with the purpose of enhancing student interaction and engagement. The issue of placing the focus on student talk and student-to-student discussion is related to the choice of materials for EFL classrooms since group and pair activities and other forms of student interaction call for stimulating, motivating, authentic and thought-provoking albeit controversial content. The need to provide such content may challenge the idea of following one particular textbook throughout the entire course of study.

\section{METHODOLOGY: APPROACHES TO THE USAGE OF MATERIALS}

The reliance on textbooks in ELT is viewed differently. Arguments in favor of using textbooks suggest that they offer a clear framework, create "a sense of structure and progress", provide ready-made activities and enable students to progress on their own (UR, 2012, p. 198). J. Haycroft refers to textbooks as "psychologically important to students" (HAYCROFT, 1998, p. 126). On the other hand, textbooks might not offer sufficient or relevant material (GABRIELATOS, 2004, p. 28) and cannot suit all learning and teaching contexts (CUNNINGHAM, 1995, p. 5-6; DENDRINOS, 1992, p. 39-47). 
Our professional view is that nowadays, with the abundance of Internet resources and the efficiency of online learning platforms, it is feasible for language teachers to create their own resource bank drawing on what is available on the Internet. A major issue with textbooks is that they have a limited shelf life and quickly fall out of touch with the ever-changing world outside the classroom. A 2005 textbook would still be focusing on SMS messages as a popular means of communication, whereas as early as in 2010 Facebook, Twitter, mobile apps, etc. were already playing a huge role in people's daily lives.

The idea of rejecting textbooks has been around for decades. Back in 1975, D. Crystal and D. Davy pointed out that textbook language "stands far away from that real, informal kind of English which is used very much more than any other during a normal speaking lifetime" (CRYSTAL; DAVY, 1975, p. 2). Empirical studies have revealed multiple times that contrived textbook interactions differ from their authentic counterparts in a range of parameters, such as the choice of grammar and vocabulary, the number and duration of pauses, the presence of hesitation fillers, overlapping, etc. and, ultimately, also differ in the cultural aspect of interaction and the cultural content (GILMORE, 2004, p. 365).

Although modern textbooks tend to feature conversations increasingly closer resembling natural ones (GILMORE, 2004, p. 363), there are still multiple gaps between the textbook and the real world of the English language and culture (GILMORE, 2007, p. 99). There have been frequent complaints about conventional textbook materials being too contrived and bereft of the actual topics that people discuss in their everyday lives, and more experienced teachers acknowledge the benefits of using materials that mirror what is going on in the real world (MCANDREW; MARTINEZ, 2002, p. 2). R. M. Paige et al. concluded that a lot of textbooks represent culture from a "tourist's perspective", with the cultural content being fairly superficial (PAIGE et al., 2003, p. 209).

It is worth mentioning the human factor that comes into play when textbooks are created. According to C. Alptekin, there is always a certain degree of subjectivity on the part of textbook writers no matter to what lengths they go to avoid stereotyping (ALPTEKIN, 1993, p. 142). Others have also suggested that textbook content reflects "the writer's own artefact" rather than the genuine reality (NOSTRAND, 1989, p. 50). In short, "most textbook writers are native speakers who consciously or unconsciously transmit the views, values, beliefs, attitudes, and feelings of their own English-speaking society" (ALPTEKIN, 1993, p. 138; FLORENT; WALTER, 1989; CLARKE; CLARKE, 1990).

To further challenge the validity of the textbook-only approach, research has been conducted to demonstrate that when students are not restricted by the topics of a textbook, both their receptive and productive skills could be enhanced (BONYADI; ZEINALPUR, p. 391). A number of studies have revealed that allowing students to select their own topics has a positive impact on their motivation to read (a receptive skill). S. Kragler maintains that "self-selection allows students more latitude to be deeply involved with the learning process, thus fostering an interest in, as well as developing an ownership of the reading process" (KRAGLER, 2000, p. 4). Similarly, E. J. Sewell points out that "allowing students to self-select their books results in more involvement and thus more motivation to read" (SEWELL, 2003, p. 5). The same view is shared by J. E. Threadkell (THREADKELL, 2010). 
Allowing students to select their own topics for writing can also favorably influence their performance. C. Bereiter and M. Scardamalia consider self-selection of topics as well as engagement in expressive writing (e.g., personal narrative) to be the best method of improving students' writing skills (BEREITER; SCARDAMALIA, 1982). An empirical study conducted by J. P. Wolf revealed the advantages of self-selected topics over textbook-assigned topics in terms of boosting learners' confidence and improving their perception of knowledge and argumentative writing skills (WOLF, 2013).

Nowadays there exist two general approaches in moving away from textbook dominance. Firstly, textbooks can be totally abandoned. An example of such an approach is Dogme ELT (THORNBURY, 2000; MEDDINGS; THORNBURY, 2009; BRITISH COUNCIL, 2017). The proponents of this methodology reject pre-packaged materials and maintain that teachers should be looking for "ways of exploiting the learning opportunities offered by the raw material of the classroom, that is the language that emerges from the needs, interests, concerns and desires of the people in the room" (ELT DOGME, 2012). Dogme's teaching is "conversation-driven", "focused on emergent language" and "materials-light" (MEDDINGS; THORNBURY, 2009, p. 8).

Another and less radical strategy revolves around tailoring the existing textbook to suit students' needs and abilities by adapting, omitting, adding, re-ordering, etc. (TOMLINSON, 1998). Besides, some educationalists advocate a critical approach to using the existing textbook, which involves encouraging students to critically analyze its content. According to B. Kumaravadivelu, learners could be asked "to discuss how topics could be dealt with differently, from the point of view of their own linguistic and cultural perspective" (KUMARAVADIVELU, 2003, p. 156). J. Gray expresses an analogous view and says that teachers need to encourage learners "to view materials as more than linguistic objects", which helps reverse the one-way flow of information (GRAY, 2000, p. 281).

\section{THE MODEL OF CREATING EFL CONTENT}

A major question that needs to be addressed is which of the abovementioned approaches should be taken and how to create the optimal bank of materials in the Russian ELT context. There are several factors which can potentially determine this choice:

1. The nature of the contemporary Russian ELT context. Firstly, EFL classes in Russian universities are not as ethnically, culturally and religiously diverse as in countries such as Australia or the United Kingdom, which allows for more freedom and flexibility on the teacher's part in terms of material selection. Secondly, in Russian culture, direct expression of one's opinion is quite common. Thirdly, Russian citizens are habitually exposed to all sorts of burning issues through mass media and the Internet. Russia has been in the spotlight of the global media over the last few years due to multiple controversial news items. On top of that, many of the topics mentioned in this article have been historically relevant within the country, and virtually every citizen has something to say on this or that subject.

2. The existence of recently produced textbooks which do include more or less authentic rather than contrived content. Textbooks that have been in common use over the last decade, such as Upstream (EVANS; OBEE, 2008) and New 
English File (OXENDEN; LATHAM-KOENIG, 2008), feature fairly conventional content. However, there are more recent publications available in Russia that tend to focus on more profound and often overlooked aspects of the life and culture of people in English-speaking countries. An example of such a textbook would be Innovations: A Course in Natural English (DELLAR; WALKLEY, 2015). The focus of the textbook is the contemporary British culture, and it includes topics pertaining to it, such as politics, youth unemployment and even war and terrorism (DELLAR; WALKLEY, 2015, p. 82). Another prominent feature of the textbook is the use of near-authentic dialogues containing mildly offensive words which are normally avoided in EFL textbooks (e.g., "bloody" and "crap"). Phonetically, these dialogues feature regional and social accents of Great Britain, which learners are likely to encounter in real life interactions. However, it also bears noticing that such textbooks tend to be restricted to the culture of the UK, and as has already been mentioned, it is the British model that has dominated the ELT in Russia (PROSHINA, 2006, p. 79).

3. Wide access to supplementary materials and authentic sources. Unlike in some countries (e.g., China, where services such Google and YouTube are banned), in Russia there are currently no restrictions on accessing authentic content on the Internet, such as websites of TV and radio broadcasters in English-speaking countries, YouTube channels, etc.

Taking these factors into consideration, the model described below can be recommended for implementation in the Russian EFL context both at public institutions and private schools. It does not feature complete textbook abandonment (as in Dogme ELT), but does include textbook customization (THORNBURY, 2013) and features of the cultural critical analysis approach (KUMARAVADIVELU, 2003; WALLACE, 1992).

1. The fusion (combined usage) of textbooks with the purpose of the comprehensive coverage of the cultures of the two English-speaking countries that Russian learners are most likely to experience: the UK and the USA. In 2016 these two countries welcomed $7 \%$ and $9 \%$ respectively of the total number of Russian students going to study abroad, whereas other English-speaking countries welcomed a significantly smaller number of Russians, with Australia, for example, welcoming only 1.6\% (UNIPAGE, 2017). The most recent publications available for this purpose include the already mentioned Innovation: $A$ Course in Natural English (DELLAR; WALKELY, 2015), New Headway (SOARS; SOARS; HANCOCK, 2015) and American Headway (SOARS; SOARS; HANCOCK, 2016). They include such topics as culture clashes, fruits of war, gender matters, politics, terrorism, youth unemployment and obsessions, which are relevant for both Russian and English-speaking cultures and therefore fit the idea of critical analysis of materials from the students' cultural perspective (LITTLEJOHN; WINDEATT, 1988, p. 175).

2. The usage of supplementary inauthentic ELT materials on controversial topics that are lacking in the textbooks described above. Some examples of the compilation of such materials include Taboos \& Issues (MCANDREW; MARTINEZ, 
2002), Instant Discussions (MCANDREW; MARTINEZ, 2003), Impact Values (DAY; YAMANAKA; SHAULES, 2002) and Impact Topics (DAY; YAMANAKA, 2002). They feature a wide variety of controversial topics and both readymade and adaptable activities in such topics as dating, same-sex couples, love affairs, alcohol abuse, abortion, the death penalty, etc.

3. The usage of authentic materials. The nature of the authenticity of materials is viewed differently in foreign language teaching. Most educators agree, however, that authentic materials are those created for native speakers, not for language learners, and therefore do not have an inherent teaching purpose (JORDAN, 1997, p. 113; KILICKAYA, 2004, p. 1). Unlike their contrived textbook counterparts, authentic materials are used in the genuine world outside the classroom in the real communication of native speakers (KELSEN, 2009, p. 2). The methodological advantages of using authentic materials, as described by researchers, lie in the fact that they expose learners to genuine language, allow a more creative approach to language instruction and have a positive impact on learners' motivation (KILICKAYA, 2004, p. 2). From the cultural point of view, authentic materials bring students closer to the target culture because they are represented by such artefacts as radio and TV broadcasts, advertising, music, newspapers, literature, websites as well as spontaneous everyday discourse (GILMORE, 2007, p. 107; PEACOCK, 1997, p. 144). One of today's most powerful resources of authentic materials is YouTube, which incorporates multiple forms of authentic materials (video blogs, broadcasts, music, etc.). YouTube's viability as a supplementary tool for language instruction has been vividly demonstrated in a study by B. Kelsen (KELSEN, 2009) conducted among second-year university students in Taiwan.

For the Russian context, the range of sources of authentic materials could include the following:

1. Radio and TV broadcasts. All English-speaking cultures have organizations which make broadcasts on current issues all over the world: the BBC in the UK, NPR and CNN in the USA, ABC in Australia, etc. For teachers' and learners' convenience, many programs are available as podcasts, e.g. BBC Global News Podcast updated daily (BBC, 2017b). A cursory look at the content of these resources will reveal the following concerns produced in idiomatic authentic language: terrorist extremism in Afghanistan, a famous film producer facing sexual harassment charges (BBC, 2017), a teenage immigrant seeking an abortion, transgender issues (NPR, 2018a), the possibility of legalizing drugs in New Zealand, a police crackdown on a gay nightspot in Nigeria (ABC, 2017).

2. The world's top newspapers such as The Guardian, The New York Times, etc. (4 INTERNATIONAL..., 2017).

3. A variety of YouTube materials which can expose Russian learners to both professional and everyday authentic discourse. 
Specifically, a sample range of controversial topics for an advanced English course in Russia could include the following content: culture clashes, gender matters, fruits of war (SOARS; SOARS; HANCOCK, 2015), politics and elections, taboos and embarrassing situations, celebrity and scandal (DELLAR; WALKELY, 2015), politically incorrect jokes, prostitution, abortion, transsexuality, gun violence, national stereotypes, immigration and racism, marriage equality, euthanasia, corruption, addictions, drugs legalization (MCANDREW; MARTINEZ, 2002), secret romances and animal rights (DAY; YAMANAKA; SHAULES, 2002). It is important to note, however, that it is always at the teacher's discretion to select which topics are appropriate for usage in their particular classroom. It would be well-advised to conduct a survey among the students (possibly an anonymous one, via Moodle or another eLearning platform) to find out whether everyone would feel comfortable working on this or that topic.

\section{SAMPLE LESSON ACTIVITIES ON A CONTROVERSIAL TOPIC}

We shall present sample activities as part of a lesson dedicated to the topic of military service. This topic is not normally covered per se in ELT textbooks; however, military service, which is mandatory for Russian male citizens between 18 and 27 years of age, is something that most Russian students definitely have much to say about, therefore a lesson on such a topic can prove to be quite valuable in terms of enhancing students' productive skills.

One of the key components of effective lesson planning and preparation is lesson variety. Varied lessons facilitate more productive learning, and it is recommended to diversify different lesson components to suit learners' needs and personal characteristics. In our lesson plan we apply the following variation strategies (SCRIVENER, 2011; UR, 2012, p. 21-22):

1. Organization. The lesson plan includes individual, pair and group work. Further variety is to be achieved by getting students to change their speaking partners throughout the lesson.

2. Materials. The lesson plan includes the use of printed materials and multimedia materials (audio and video).

3. Skills. The lesson plan focuses on multiple productive and receptive skills.

In our lesson plan, we adhere to the principle of eliciting target language from students rather than leaving it to the teacher to explain it. Elicitation is considered crucial in pedagogy in general. In R. Gagne's popular model of instructional events, "stimulating the recall of prior learning" (i.e. knowledge retrieval) precedes "presenting the content" (KRUSE, 2018, p. 1). In ELT, elicitation is supposed "to make classrooms more learner-centered, and help learners make connections between the old and the new" (CHOUDHURY, 2010, p. 312). Besides, according to J. Scrivener, learners "probably know a lot more than we may give them credit for", and "starting with what they know is a productive way to begin new work" (SCRIVENER, 2011, p. 73). Another vital principle (and it is ultimately underpinned by the usage of thought-provoking topics) is the personalization of language practice, i.e. use of language that involves learners' sharing of 
their experience, knowledge, opinions or feelings (THORNBURY, 2006, p. 161). Personalization is believed to positively affect classroom dynamics and is considered one of the "commandments" for motivating language learners (THORNBURY, 2006, p. 72; p. 138).

The lesson profile, stages and procedures are illustrated in the tables below ${ }^{3}$.

Table 1 - Lesson profile (Acronyms: $\mathrm{T}=$ teacher, $\mathrm{Ss}=$ students, $\mathrm{WB}=$ whiteboard, $\mathrm{sb}=$ somebody, sth = something)

\begin{tabular}{|c|c|}
\hline Teacher & $\mid-/-$ \\
\hline Lesson type & Language: vocabulary, reading, listening, speaking \\
\hline Time \& place & $-1-$ \\
\hline Lesson aims & $\begin{array}{l}\text { - to learn and practice vocabulary related to the topic of military service } \\
\text { - to practice listening and reading comprehension skills }\end{array}$ \\
\hline Materials & $\begin{array}{l}\text { 1. In the Army (a song by Status Quo): audio and gapped lyrics (EARMUSIC, } \\
\text { 2010). } \\
\text { 2. Campaign 1: English for the Military (MELLOW-CLARK, DE ALTAMIRANO, } \\
\text { 2004). } \\
\text { 3. Which Countries Still Use the Military Draft? (YouTube video) (NOWTHIS- } \\
\text { WORLD, 2015). } \\
\text { 4. What it's Like to Serve in South Korea's Mandatory Military Service (You- } \\
\text { Tube video) (TECH INSIDER, 2017). } \\
\text { 5. In Australia, Decades of Abuse Against Military Recruits Comes to Light } \\
\text { (NPR News podcast) (NPR, 2018a). } \\
\text { 6. A set of discussion questions on the topic of military service (ESL DIS- } \\
\text { CUSSIONS.COM, 2018). } \\
\text { 7. Rite of Passage (BBC Documentary podcast) (BBC, 2018b). }\end{array}$ \\
\hline $\begin{array}{l}\text { Expected } \\
\text { number of } \\
\text { students }\end{array}$ & $10-15$ \\
\hline Student level & pre-intermediate to upper-intermediate \\
\hline Total duration & $90 \mathrm{~min}$ \\
\hline $\begin{array}{l}\text { Anticipated } \\
\text { problems \& } \\
\text { solutions }\end{array}$ & $\begin{array}{l}\text { 1. Unfamiliarity with subject-specific vocabulary. } \\
\text { Solution: vocabulary \& grammar elicitation and illustration. } \\
\text { 2. Classroom heterogeneity. } \\
\text { Solution: proper grouping and pairing of students. }\end{array}$ \\
\hline
\end{tabular}

Table 2 - Lesson stages and procedures

\begin{tabular}{|l|l|l|c|}
\hline \multicolumn{1}{|c|}{ Stage } & \multicolumn{1}{|c|}{ Procedure } & \multicolumn{1}{c|}{ Aims } & Time \\
\hline 1. Introduction & $\begin{array}{l}\text { T greets Ss and introduces the les- } \\
\text { son's agenda. }\end{array}$ & $\begin{array}{l}\text { - to gain Ss' attention and } \\
\text { create the level of expecta- } \\
\text { tion for learning }\end{array}$ & 2 min \\
\hline 2. Grouping & T groups Ss based on their level. & $\begin{array}{l}\text { - to properly group Ss } \\
\text {-to foster productive interac- } \\
\text { tion }\end{array}$ & 3 min \\
\hline
\end{tabular}

3 The structure is based on: SCRIVENER (2011) 


\begin{tabular}{|c|c|c|c|}
\hline $\begin{array}{l}\text { 3. Setting the } \\
\text { context: song } \\
\text { activity }\end{array}$ & $\begin{array}{l}\text { T explain the task following task to } \\
\text { Ss: } \\
\text { Listen to the song "In the Army" } \\
\text { by Status Quo and complete the } \\
\text { gaps in the lyrics. Try to explain the } \\
\text { meaning of the missing words. Be } \\
\text { ready to explain the main idea of } \\
\text { the song. } \\
\text { Ss listen to the song and perform } \\
\text { the given task. T elicits the spell- } \\
\text { ing, pronunciation, meaning and } \\
\text { translation of the following vo- } \\
\text { cabulary taken out from the lyrics: } \\
\text { Uncle Sam, draft, grenade, missile, } \\
\text { sergeant, shot, order, trigger. } \\
\text { Students express the main idea of } \\
\text { the song. }\end{array}$ & $\begin{array}{l}\text { - to put Ss in the context of } \\
\text { the lesson } \\
\text { - to introduce topical vocab- } \\
\text { ulary }\end{array}$ & $\begin{array}{l}15 \\
\min \end{array}$ \\
\hline $\begin{array}{l}\text { 4. Pre-teaching } \\
\text { vocabulary: } \\
\text { the Army and } \\
\text { military con- } \\
\text { scription }\end{array}$ & $\begin{array}{l}\text { T elicits Ss' prior knowledge of } \\
\text { core concepts related to the Army } \\
\text { (structure, purpose, ranks). Key in- } \\
\text { formation is put on the board. } \\
\text { T hands out copies of Unit } 4 \text { Mil- } \\
\text { itary Organisation from the text- } \\
\text { book Campaign 1: English for the } \\
\text { Military, which are to be used as a } \\
\text { quick reference further during the } \\
\text { lesson. } \\
\text { T instructs Ss to watch the video } \\
\text { Which Countries Still Use the Mili- } \\
\text { tary Draft? and be ready to explain } \\
\text { why some countries still preserve } \\
\text { compulsory mandatory service. } \\
\text { Ss watch the video and in pairs dis- } \\
\text { cuss the main idea of the video. }\end{array}$ & $\begin{array}{l}\text { - to learn / revise topical vo- } \\
\text { cabulary needed for later ac- } \\
\text { tivities } \\
\text { - to comprehend key con- } \\
\text { cepts related to military ser- } \\
\text { vice }\end{array}$ & $20 \mathrm{~min}$ \\
\hline $\begin{array}{l}\text { 5. Mandatory } \\
\text { military ser- } \\
\text { vice }\end{array}$ & $\begin{array}{l}\text { T elicits some vocabulary items } \\
\text { that would appear in the video } \\
\text { What it's like to Serve in South Ko- } \\
\text { rea's Mandatory Military Service? } \\
\text { T elicits Ss' prior knowledge about } \\
\text { mandatory military service in Rus- } \\
\text { sia. } \\
\text { T instructs Ss to watch the vid- } \\
\text { eo and compare and contrast } \\
\text { the mandatory military service } \\
\text { in South Korea and in Russia. Ss } \\
\text { watch the video, do small group } \\
\text { discussions and then report their } \\
\text { answers to the teacher. }\end{array}$ & $\begin{array}{l}\text { - to practice pre-taught vo- } \\
\text { cabulary } \\
\text { - to analyze similarities and } \\
\text { differences between the mil- } \\
\text { itary service in two countries }\end{array}$ & $\begin{array}{l}20-25 \\
\min \end{array}$ \\
\hline
\end{tabular}




\begin{tabular}{|c|c|c|c|}
\hline $\begin{array}{l}\text { 6. Free speaking } \\
\text { practice }\end{array}$ & $\begin{array}{l}T \text { instructs Ss to select any } 10 \\
\text { questions from the list (see below } \\
\text { under the table) and discuss them } \\
\text { in pairs spending no more than } 2 \\
\text { minutes on one question. }\end{array}$ & $\begin{array}{l}\text { - to allow uncontrolled per- } \\
\text { sonalized practice } \\
\text { - to practice fluency }\end{array}$ & $\begin{array}{l}20-25 \\
\min \end{array}$ \\
\hline $\begin{array}{l}\text { 7. Home assign- } \\
\text { ment and } \\
\text { follow-up }\end{array}$ & $\begin{array}{l}\text { T explains to Ss their home assign- } \\
\text { ment: } \\
\text { Listen to the BBC Documentary } \\
\text { podcast "Rite of Passage" about } \\
\text { the military service in Israel and } \\
\text { post } 2 \text { to } 3 \text { paragraphs on the } \\
\text { Moodle discussion board detailing } \\
\text { how it helps shape Israeli society } \\
\text { and what role, in your opinion, it } \\
\text { will play in Israel's future. } \\
\text { The teacher suggests some re- } \\
\text { sources for further individual ac- } \\
\text { tivities outside classroom. }\end{array}$ & to indicate future activities & $5 \mathrm{~min}$ \\
\hline
\end{tabular}

\section{Discussion questions}

1. Do you want to become a soldier?

2. Would you volunteer to become a soldier?

3. Which armed service would you join if you had to? Would you choose to join, the army, navy or air force?

4. Which job would you like to have in the army?

5. What cause would you fight/die for?

6. Why does your country have an army?

7. Do many young people in your country join the army? Why/why not?

8. Do you think soldiers are well paid?

9. Would you be a conscientious objector if your country went to war?

10. Do you think women should be soldiers?

11. Do you think LGBTI people should be soldiers?

12. Have you been in the military?

13. Do you know anyone who is in the army or who has been?

14. Have you ever lived in a country at war?

15. If you were the partner of a soldier who had just been sent to fight in a war, what would you include in his luggage?

16. What do you think soldiers away from home miss the most?

17. What do you think soldiers find the most difficult to get used to?

18. Is abuse and bullying common in the army?

19. What are the major issues about the army of your country?

20. Why do you think people want to become soldiers?

21. What kind of person makes an ideal soldier? 
22. Is war necessary?

23. What causes countries to engage in a war?

24. Do you think it is morally wrong to kill?

25 . Has anyone in your family ever fought in a war?

26. If war could be eliminated entirely, would there still be a use for armies?

27. Do you have a problem with women fighting in wars? Why or why not?

28. What are your feelings towards the military?

29. What do you think is the worst thing about being in the army?

30. What do you think of army uniforms?

At the teacher's discretion, the NPR news report In Australia, Decades of Abuse Against Military Recruits Comes to Light can also be used as a separate discussion point during the course of the lesson (NPR, 2018a). However, as is warned by the podcast presenter, it contains highly disturbing material.

\section{CONCLUSION}

The paper historically traces the features of the Russian ELT tradition $a^{\text {nd }}$ evaluates its current state and features. Although ELT in Russia has historically been textbook-driven and the use of authentic materials was limited or even discouraged, nowadays there exist trends toward completely and partially textbook-free approaches as in many countries internationally. Such a movement away from the dry language of textbooks could prove conducive in attempting to shape the optimal content for modern Russian ELT practices - content that could enhance students' interaction and their acquisition of authentic linguistic and cultural knowledge.

The inclusion of thought-provoking controversial issues into ELT curriculum at Russian universities should not turn the classroom into a battlefield or a culture war zone. Instead, it could help make classroom interactions more open and transparent and facilitate the personalization of language practice by allowing students to have their say on topics they can relate to. As an example of such an approach, a lesson plan on the thought-provoking topic of military service with sample materials and activities has been presented based on the described approaches and principles.

It is necessary, however, to ensure that language teachers feel comfortable when working without the back-up of a textbook. This is particularly the case for non-native speakers, for whom a textbook often provides not only material, but also "moral" support. It would be beneficial, therefore, to offer training sessions to such teachers specifically on shaping productive cultural content for EFL materials that are appropriate for the Russian ELT classroom.

\section{REFERENCES}

4 INTERNATIONAL MEDIA \& NEWSPAPERS. 2016 Newspaper Web Rankings: Top 200 Newspapers in the World. Available from: http://www.4imn.com/top200/. Cited: 22 Oct. 2017.

ABC. World news. Available from: http://www.abc.net.au/news/world/. Cited: 22 Oct. 2017.

ALPTEKIN, C. "Target-language culture in EFL materials". ELT Journal, v. 47, n. 2, p. 136-143, 1993. 
BAKER, Y.; DE ALTAMIRANO, Y. B.; MELLOW-CLARK, S. Campaign 2: English for the military: student's book. Londres: Macmillan Publishers Limited, 2005.

BBC. Australia's heated same-sex marriage debate, by Phil Mercer, BBC News Sydney. Available from: http://www.bbc.com/news/world-australia-41362445. Cited: 22 Oct. 2017 a.

BBC. Global news podcast. Available from: http://www.bbc.co.uk/programmes/p02nq0gn/episodes/ downloads. Cited: 21 Oct. 2017b.

BBC. London Bridge attack: Timeline of British terror attacks, BBC News UK. Available from: http://www. bbc.com/news/uk-40013040. Cited: 21 Oct. 2017c.

BBC. Europe's growing culture wars, The Real Story Podcast. Available from: https://www.bbc.co.uk/programmes/w3csvqg7. Cited: 2 Apr. 2018 a.

BBC. Rite of Passage, The Documentary Podcast. Available from: https://www.bbc.co.uk/programmes/ w3csvqg7. Cited: 2 Mar. 2018b.

BEREITER, C.; SCARDAMALIA, M. From conversation to composition: the role of instruction in a developmental process. In: GLASER, R. (ed.). Advances in Instructional Psychology, v. 2, p. 1-64, 1982.

BONYADI, A.; ZEINALPUR, S. Perceptions of students towards self-selected and teacher-assigned topics in EFL writing. Procedia - Social and Behavioral Sciences, v. 98, p. 385-391, 2014.

BREAKING NEWS ENGLISH. Prince Harry calls for return of military service, 19 May 2015. Available from: https://breakingnewsenglish.com/1505/150519-military-service-1.html\#ixzz40hdmQjuk. Cited: 11 Jan. 2018.

BRITISH COUNCIL. Dogme: A teacher's view. Available from: https://www.teachingenglish.org.uk/article/dogme-a-teachers-view. Cited: 20 Oct. 2017.

CHAN, J. Y. H. The Role of Situational Authenticity in English Language Textbooks. RELC Journal 44(3), p. 303-317, 2013.

CHOUDHURY, A. S. Teaching vocabulary in the ESL/EFL classroom: central pedagogical issues. MJAL Journal, 2(4), p. 306-316, 2010.

CLARKE, J.; CLARKE, M. Stereotyping in TESOL materials. In: HARRISON, B. (ed.). Culture and the language classroom. Hong Kong: Modern English Publications and the British Council, 1990. p. 31-44.

CRYSTAL, D.; DAVY, D. Advanced conversational English. Harlow: Longman, 1975.

CUNNINGHAM, A. Choosing your coursebook. Oxford: Heinemann, 1995.

DAVIES, N. F. Receptive versus productive skills in foreign language learning. The Modern Language Journal, v. 60(8), p. 440-443, 1976.

DAY, R. R.; YAMANAKA, J. Impact topics. Hong Kong: Longman, 2002.

DAY, R. R.; YAMANAKA, J.; SHAULES, J. Impact values. Hong Kong: Longman Asia ELT, 2002.

DELLAR, D.; WALKELY, A. Innovations advanced: a course in natural English. London: Thomson ELT, 2015. DENDRINOS, B. The EFL coursebook and ideology. N. C. Athens: Grivas Publications, 1992.

EARMUSIC. Status Quo "In the Army Now (2010)" (official video). YouTube, 12 October 2010. Available from: https://www.youtube.com/watch?v=ObntvRcKMrE. Cited: 16 Mar. 2018.

ELT DOGME. Group description. 2012. Available from: http://groups.yahoo.com/group/dogme/. Cited: 22 Feb. 2018.

ESL DISCUSSIONS.COM. English discussion on army. Available from: https://esldiscussions.com/a/army. html. Cited: 2 Mar. 2018.

ESL DISCUSSIONS.COM. English discussion on war. Available from: https://esldiscussions.com/w/war. html. Cited: 3 Mar. 2018.

EVANS, V.; OBEE, B. Upstream upper-intermediate. Newbury: Express Publishing, 2008.

FLORENT, J.; WALTER, C. A better role for women in TEFL. ELT Journal, 43(3), 45-78, 1989.

GABRIELATOS, C. Session plan: the coursebook as a flexible tool. IATEFL Teacher Trainers and Educators SIG Newsletter 1, p. 28-31, 2004.

GILMORE, A. A comparison of textbook and authentic interactions. ELT Journal. vol. 54/8. Oxford: Oxford University Press, p. 363-374, 2004.

GILMORE, A. Authentic materials and authenticity in foreign language learning. Language Teaching, vol. 40. Oxford: Cambridge University Press, p. 97-118, 2007.

GRAY, J. The ELT Coursebook as cultural artefact: how teachers censor and adapt. ELT Journal. vol. 54, Issue 3, p. 274-283, 2000.

GRAY, J. The construction of English: culture, consumerism and promotion in the ELT global coursebook. Basingstoke: Palgrave Macmillan, 2010. 
HAYCROFT, J. An introduction to English language teaching. London: Longman, 1998.

HIEBERT, H. I.; LEIGH, A. M.; MENON, S. Are there alternatives in reading textbooks? An examination of three beginning reading programs. Reading \& Writing Quarterly, v. 21:1, p. 7-32, 2005.

IVANOVA, V.; TIVYAEVA, I. Teaching foreign languages in Soviet and present-day Russia: a comparison of two systems. Zbornik Instituta za pedagoska istrazivanja. v. 47(2), p. 305-324, 2015.

JESPERSON, O. How to Teach a Foreign Language. London: George Allen and Unwin, 1904.

JOHNSON, G.; RINVOLUCRI, M. Culture in our classrooms: teaching language through cultural content. In: JOHNSON, G.; RINVOLUCRI, M. Culture in our classrooms: teaching language through cultural content. Peaslake: Delta Pub., 2010. p. 7-18.

JORDAN, R. R. English for academic purposes: A guide and resource for teachers. Cambridge: Cambridge University Press, 1997.

KACHRU, Y. Culture, context, and writing. In: HINKEL, E. (ed.). Culture in Second Language Teaching and Learning. Cambridge: Cambridge University Press, p. 75-89, 1999.

KELSEN, B. Teaching EFL to the iGeneration: a survey of using YouTube as supplementary material with college EFL students in Taiwan. CALL-EJ On-line, v. 10(2), p. 1-18, 2009.

KILICKAYA, F. Authentic materials and cultural content in EFL classrooms. The Internet TESL Journal. v. X, n. 7, 2004. Available from: <http://iteslj.org/Techniques/Kilickaya-AutenticMaterial.html>. Cited: 1 Mar. 2018.

KILICKAYA, F. Guidelines to evaluate cultural content in textbooks. The Internet TESL Journal, v. X, n. 12, 2004. Available from: http://iteslj.org/Techniques/KilickayaCulturalContent/. Cited: 10 Mar. 2018.

KRAGLER, S. Choosing books for reading: an analysis of three types of readers. Journal of Research in Childhood Education, v. 14(2), p. 133-141, 2000.

KRUSE, K. Gagne's nine events of instruction: an introduction. Available from: http://www.e-learningguru. com/articles/art3_3.htm. Cited: 16 Mar. 2018.

KUMARAVADIVELU, B. Beyond methods: macrostrategies for language teaching. New Haven: Yale University Press, 2003.

LEWIS, G. L. Foreign and second language teaching in the USSR. ETIC Occasional Paper No. 1, The British Council English-Teaching Information Centre, London, 1962.

LITTLEJOHN, A.; WINDEATT, S. Beyond language learning: perspectives on materials design. In: JOHNSON, R. (ed.). The Second Language Curriculum. Cambridge: Cambridge University Press, 19088. p. 155175.

MCANDREW, R.; MARTINEZ, R. Taboos \& issues. Boston: Thomson \& Heinle, 2002. (Language Teaching Publication Series).

MCANDREW, R.; MARTINEZ, R. Instant discussions. Boston: Thomson \& Heinle, 2003. (Language Teaching Publication Series).

MCKAY, S. L. Teaching English as an international language: implications for cultural materials in the classroom. TESOL Journal, v. 9, n. 4, p. 7-11, 2000.

MEDDINGS, L.; THORNBURY, S. Teaching Unplugged: Dogme in English language Teaching. Peaslake: Delta Publishing, 2009.

MELLOR-CLARK, S.; DE ALTAMIRANO, Y. B. Campaign 1: English for the military: student's book. Macmillan: Macmillan Publishers Limited, 2004.

MONK, B.W. Foreign Language Teaching in the Soviet Union: Continuing the Trend. Journal of Russian Studies 50, p. 28-37, 1986.

NOSTRAND, Howard Lee. Authentic texts and cultural authenticity: An editorial. 1989. The Modern Language Journal, v. 73. n. 1. p. 49-52.

NOWTHISWORLD. Which countries still use the military draft? YouTube, 17 Oct. 2015. Available from: https://www.youtube.com/watch?v=iAORdorAk_k. Cited: 12 Feb. 2018.

NPR. In Australia, Decades of Abuse Against Military Recruits Comes to Light. Available from: http://www. npr.org/sections/news/. Cited: 19 Mar. 2018a.

NPR. News. Available from: http://www.npr.org/sections/news/. Cited: 22 Mar. 2018b.

OBDALOVA, O. A. New approaches to organization of students' self-study activity and its informational and methodic provision when teaching foreign languages. Yazyk i kultura (Language and Culture), 1, p. 96-104, 2008.

OXENDEN, C.; LATHAM-KOENIG, C. New English File upper-intermediate. Oxford: Oxford University Press, 2008. 
PAIGE, R. M.; JORSTAD, H. L.; SIAYA, L.; KLEIN, F.; COLBY, J. Culture learning in language education. In: LANGE, Dale L. (ed.). Culture as the core: Perspectives on culture in second language learning. Greenwich: IAP; Connecticut, 2003. p. 173-236.

PEACOCK, M. The effect of authentic materials on the motivation of EFL learners. ELT Journal, v. 51(2), p. 144-156, 1997.

PROSHINA, Z. Russia English: Status, attitudes, problems. The Journal of Asia TEFL, v. 3, n. 2, p. 79-101, 2006.

RASSKAZOVA, T.; GUZIKOVA, M., GREEN, A. English language teacher development in a Russian university: context, problems and implications. Ampersand, v. 4, p. 1-9, 2017.

RASSOKHA, M. Conditions for English language learning in Russia. In: SUNG, K.; SPOLSKY, B. (ed.). Conditions for English Language Teaching and Learning in Asia. Cambridge: Cambridge Scholars Publishing, 2004. p. 37-61.

RIVERS, Wilga. Principles of Interactive Language Teaching. 2007. Available from: http://www.edevaluator.org/rivers/10Principles_0.html. Cited: 1 Feb. 2013.

SBS. How close are we to marijuana legalisation in Australia. Available from: http://www.sbs.com.au/ guide/article/2016/12/02/how-close-are-we-marijuana-legalisation-australia. Cited: 4 Dec. 2017.

SCRIVENER, J. Learning teaching: the essential guide to English language teaching. 3th ed. Macmillan: Macmillan Education, 2011.

SEWELL, E. J. Students' choice of books during self-selected reading. EDRS opinion papers, p. 1-25, 2003. SOARS, L.; SOARS, J.; HANCOCK, P. New Headway advanced student's book. Oxford: Oxford University Press, 2015.

SOARS, L.; SOARS, J.; HANCOCK, P. American Headway third edition: level 5 student book: with Oxford online skills practice pack. Oxford: Oxford University Press, 2016.

TECH INSIDER. What it's like to serve in South Korea's mandatory military service? YouTube, 30 May 2017. Available from: https://www.youtube.com/watch?v=WsVQ7dyyc_A. Cited: 29 Mar. 2018.

TER-MINASOVA, S. Foreign language teaching in a changing Russia. In: HICKEY, T.; WILLIAMS, J. (ed.). Language, education, and society in a changing world. Dublin: Iraal/Multilingual Matters Ltd., 1996. p. 86-92. TER-MINASOVA, S. Traditions and innovations: English language teaching in Russia. World Englishes, 24 (4), p. 445-454, 2005.

TER-MINASOVA, S. Problems and Challenges of Teaching a Foreign Language as a Means of Professional Communication. Journal of Moscow University. Series 19: linguistics and cross-cultural communication, 3, p. 7-13, 2006.

TER-MINASOVA, S. Language, linguistics and life: a view from Russia. 2th ed. Moscow: Krasand, 2009.

TER-MINASOVA, S. ELT in a changing Russia: traditions and innovations. Keynote address at the Asian conference on education (ACE), Osaka, Japan, 2 Nov. 2013.

THE INTERNET TESL JOURNAL. Conversation Questions: War. Available from: http://iteslj.org/questions/ war.html. Cited: 1ㅇ№v. 2017.

THORNBURY, S. A Dogma for EFL. IATEFL Issues, v. 153(2), p. 2, 2000.

THORNBURY, S. An A-Z of ELT. Oxford: Macmillan Education, 2006.

THORNBURY, S. Resisting coursebooks. Critical Perspectives on Language Teaching Materials. Basingstoke: Palgrave Macmillan, 2013. p. 204-223.

THREADKELL, J. E. Seeking new perspectives on self-selected and teacher-assigned texts: exploring adolescent readers experiences. 2010. Unpublished Doctoral dissertation - University of Manitoba, Manitoba, 2010.

TOMLINSON, B. Materials development in language teaching. Cambridge: Cambridge University Press, 1998.

UNIPAGE V.1.3.0. International Students. Available from: https://www.unipage.net/ru/student_statistics. Cited: 21 Oct. 2017.

UR, P. A Course in English Language Teaching. 2th ed. Cambridge: Cambridge University Press, 2012.

WALLACE, C. Critical literacy awareness in the EFL classroom. In: FAIRCLOUGH, N. (ed.). Critical Language Awareness. Harlow: Longman, 1992. p. 59-92.

WOLF, J. P. Exploring and contrasting EFL learners' perceptions of textbook-assigned and self-selected discussion topics. Language Teaching Research, v. 17(1), p. 49-66, 2013. 